\title{
Correlation Between Sleep Quality and Emotion Regulation in X University Students
}

\author{
Ignasia Farren $^{1 *}$ Agoes Dariyo $^{2}$
}

\author{
${ }^{1}$ Alumni of Faculty of Psychology, Tarumanagara University, Jakarta 11440, Indonesia \\ ${ }^{2}$ Faculty of Psychology, Tarumanagara University, Jakarta 11440, Indonesia \\ *Corresponding author. Email: farenignasia@yahoo.com
}

\begin{abstract}
College students have many activities that can cause poor sleep quality, such as academic demands, activities after lecture, and part-time work. Poor sleep quality can cause students to experience increased stress so it is easy to feel negative emotions, such as anger and sadness. This shows poor emotion regulation. This study aims to determine the relationship between sleep quality and emotion regulation in X University students, Jakarta. Participants in this study were 86 active X University students aged between 18 and 25 years old. This research is a correlational research and without experiments. Sleep quality is measured by the PSQI (Pittsburgh Sleep Quality Index) questionnaire and emotional regulation is measured by ERQ (Emotion Regulation Questionnaire). The research data distribution is normal and analyzed using the Pearson correlation test. The correlation between sleep quality and emotion regulation in $\mathrm{X}$ University students obtained $\mathrm{p}=0.855(\mathrm{p}>0.05)$. This shows that sleep quality has no significant correlation with emotional regulation in $\mathrm{X}$ University students. The correlation between sleep quality with cognitive reappraisal dimensions was obtained $\mathrm{p}=0.615(\mathrm{p}>0.05)$ and with expressive suppression reappraisal dimensions $\mathrm{p}=$ 0.274 ( $p>0,05$ ). This shows that sleep quality does not have a significant correlation with the two dimensions of emotion regulation in X University students. The conclusion of this study is that there is no significant correlation between sleep quality and emotion regulation, both the dimensions of cognitive reappraisal and expressive suppression reappraisal in X University students.
\end{abstract}

Keywords: Sleep quality, emotion regulation, college students

\section{INTRODUCTION}

Carpenito said that sleep is one of the physiological needs possessed by every human being [13]. According to Guyton and Hall, each individual needs a different amount of time or duration to meet their rest and sleep needs [24]. Each individual's sleep needs are different and depend on the daily activities undertaken [13]. Every individual, including students who are currently studying at the tertiary level, has a routine in their daily life. In carrying out this routine, individuals sometimes encounter various problems, namely; (a) changes in their living arrangements, such as roommates; (b) social life, such as new circle of friends and substance abuse; (c) biological development, eg sleep time; and (d) the financial situation, for example the freedom of the parents to use money. In addition, there are academic demands such as exams, papers, and deadlines to increase this stress potential. This can cause lack of quality sleep to become a common occurrence among college students [12].

Students do not have good sleep quality [31]. Poor sleep quality in college students not only results in academic success, but also behavioral and emotional problems. Poor sleep quality will make someone sleepy easily during teaching and learning activities so that students have difficulty understanding lecture material. As a result, students can also experience failure in achieving their learning achievements. On the other hand, if a student has good sleep quality, he will feel refreshed when attending lectures, and he can receive lessons well. Thus, he can achieve good learning achievement too.

According to Potter \& Perry, various things can affect student rest and sleep patterns, namely the academic demands of lectures, after-class activities, and part-time jobs [24]. Students sleep late and wake up earlier during lectures. As a result, sleep time and physiological needs are not met, so often sleepy during the day.

The inability to regulate life patterns can cause sleep disorders in students [13]. As a result, sleep is lacking or even not quality. Sleep quality is a state when an individual sleeps which results in freshness and fitness when awakened [7]. Poor or bad sleep can affect the emotional regulation of these individuals [20]. This poor quality of sleep can cause problems later in life, such as decreased concentration in learning and health problems. As a result, individuals become prone to negative 
emotions, such as anger and sadness. This is an indication of poor emotional regulation.

Gross defines emotional regulation as the way individuals influence what emotions, when, and how these emotions are experienced and expressed. Emotional regulation is important to have so that individuals can control emotions when faced with problems and regulate mood [29]. Emotional regulation can result in increased or decreased emotions involving both positive and negative emotions. Individuals who can control their emotions can help adjust to the conditions that occur in their environment, put themselves in appropriate situations, and distinguish when and how emotions are shown.

According to Garnefski et al, the weight or lightness of a problem depends on the way the individual reacts to it, the individual's mindset, and the way the individual deals with it [29]. The way individuals deal with a problem often involves emotions in expressing the mood they are experiencing as a result of a particular stimulus from the problem. An example is when an individual is feeling angry emotions, it will be expressed through talking loudly with the people around him.

Previous research on sleep quality by Setyowaty, entitled The Correlation between Sleep Quality and Emotional Stability and Academic Achievement of Voca Erudita Choir Student Academic Achievement at UNS (Universitas Negeri Surakarta). The results of this study indicate that there is a significant relationship between sleep quality and emotional stability. Individuals with good quality sleep can maintain emotional stability so they are not tired, not anxious, not lethargic, do not yawn, are not sleepy, do not have headaches the next day, and trigger good behavior. Research on this study measured the emotional stability variable, while this study measured the emotional regulation variable [13].

Individuals with academic demands such as students are very prone to experiencing poor sleep quality. This is evidenced by the research of Manalu, Freari, and Butar Butar in 2012 on students of the Faculty of Medicine, University of Riau, entitled The Correlation between Sleep Quality and Blood Pressure in Students of the Faculty of Medicine, University of Riau Class of 2012. Participants in this study were 220 teenagers. The results showed that the participants in the study had poor sleep quality and had no impact on increasing blood pressure [18].

Research on the Correlation between Sleep Quality and Emotional Stability with the Academic Achievement of the Voca Erudita Choir of UNS (Negeri Surakarta University) has limited participants to students who are members of the choir at Negeri Surakarta University only. Research on the Relationship of Sleep Quality with Blood Pressure in Students of the Faculty of Medicine, University of Riau Class of 2012 has limited participants only students of the Faculty of Medicine, University of Riau Class of 2012 only. Compared to these studies, this study had participants including all X University students. Research on the Relationship between Sleep Quality and Emotional Stability and Academic Achievement of Voca Erudita Choir Active Students UNS (Surakarta State University) was conducted in the city of Surakarta.
Research on the Relationship between Sleep Quality and Blood Pressure in Students of the Faculty of Medicine, University of Riau, Class of 2012 was conducted in Riau City. Compared to these studies, this research was conducted in a different city, which was Jakarta.

Stress levels can affect a person's emotional regulation [8]. Therefore, people who have the same stressor can be classified under the same emotional level. The $\mathrm{X}$ University students group has the same variation of stressors, both academically and non-academically.

On the basis of the above research results, it can be said that an individual who wants to have good emotional regulation must be based on good sleep quality. If a person's sleep quality is poor, then his emotional regulation is also bad. The reason is that good or bad quality of sleep of an individual will also have an impact on how that individual regulates emotions. On the basis of this thought, researchers are interested in conducting research on the relationship between sleep quality and emotional regulation in $\mathrm{X}$ University students. Formulation of the problem: is sleep quality related to emotional regulation in X University students?

\section{METHODS}

\subsection{Research Participants}

Participants in this study were active undergraduate students at $\mathrm{X}$ University. The characteristics of the participants in this study were students who belonged to the age group ranging from 18 to 25 years. This research has no limitations, either on gender, religion, race or culture. The minimum sample size in this study was set at 18 people [27]. The minimum sample size for correlational research is 50 people [11]. The sample in this study was 86 people who were active students of $\mathrm{X}$ University. This means that the number of participants in this study was representative. The research population in this study included all active students of X University.

\subsection{Measuring Instruments}

This study uses measuring instruments PSQI (Pittsburgh Sleep Quality Index) and ERQ (Emotional Regulation Questionnaire). The PSQI is a sleep quality measurement instrument that has been widely used in various countries [23]. The PSQI is used to distinguish between good and bad sleep quality for individuals by measuring seven sleep quality domains, which include: (1) subjective sleep quality, (2) sleep latency, (3) sleep duration, (4) habitual sleep efficiency, (5) sleep disturbance, (6) sleep medication, and (7) daytime dysfunction [23]. The ERQ is a ten-item scale designed by James J. Gross and Oliver P. John in 2003 with the aim of measuring the tendency of respondents to regulate their emotions when faced with stressful situations [10]. This goal can be done in two 
ways, namely cognitive reappraisal and expressive suppression reappraisal. Participants answered each question on a 7-point Likert scale ranging from 1 (strongly disagree) to 7 (strongly agree). Participants were asked to answer according to the alternative answers provided with four answer choices with different scores, namely almost always, often, sometimes, and almost never.

Several countries have used the PSQI to measure sleep quality, including America, India, Japan, Arabic, Korean, Spanish, Persian, Italian, and Portuguese [28]. Likewise, ERQ has been used to measure the regulation of individual emotions in various countries, such as in Spain, France, Australia, and the UK [1]. The sensitivity level of the PSQI was $89.6 \%$ and the specificity was $86.5 \%$ [3]. The Cronbach PSQI Alpha value is $87 \%$ [4]. All questions in the ERQ have been tested for their validity and are widely used to measure emotional regulation and are declared valid in various countries, such as Spain, France, Australia and the UK [1]. In addition, it was found that the ERQ items were internally consistent across different age groups and cultures. The Cronbach ERQ Alpha value is 0.7 .

\section{FINDINGS}

In this study, there were participants with good sleep quality, namely 16 participants $(17.4 \%)$, participants with poor sleep quality, as many as 70 participants $(82.6 \%)$. This grouping is based on the provision that if the score is $<5$, it means that the individual has good sleep quality, and if the score is $\geq 5$, it means that the individual has poor sleep quality [23].

In this study, there were male participants with good sleep quality, as many as 5 people $(5.8 \%)$, while 32 participants $(37.3 \%)$ had poor sleep quality. In addition, there were female participants with good sleep quality, as many as 10 participants $(11.6 \%)$, while the sleep quality was poor, as many as 39 participants (45.3\%)

The results with the Pearson correlation test showed that there was no significant relationship between sleep quality and emotional regulation. The correlation test between sleep quality and emotional regulation showed a significance value of $p=0.779(p>0.05)$. This shows that sleep quality and emotional regulation have a statistically insignificant relationship ( $\mathrm{p}>0.05$ ).

The results of the Levene test showed that the data variance was not different or homogeneous ( $p$ value $=$ $0.752,>0.05)$. The results of the independent $t$-test analysis showed that as many as 71 participants with poor sleep quality had an average emotional regulation score of 49.4286 and 15 participants with good sleep quality had a mean emotional regulation score of 50.8750. The value of the $95 \%$ confidence interval is between -6.18402 to 3.29116. From the statistical test results above, it can be said that there is no significant difference between the emotional regulation scores of participants who have good and bad sleep quality $(\mathrm{p}$ value $=0.545,>0.05)$.

\section{DISCUSSIONS}

Research on the Correlation between Sleep Quality and Emotion Regulation in $\mathrm{X}$ University Students was conducted in the Jakarta area, Indonesia. Based on the results of the literature study that had been conducted, the researcher hypothesized that there was a correlation between sleep quality and emotional regulation in $\mathrm{X}$ University students. Therefore, this study wanted to determine whether there was a correlation between sleep quality and emotional regulation in X University students. All data on research participants were taken during the COVID-19 pandemic in May 2020. This study involved 86 active undergraduate students at the University of $\mathrm{X}$ consisting of 37 male (43\%) and 49 female $(57 \%)$. There were 5 male participants $(5.8 \%)$ who had good sleep quality and 32 participants $(37.3 \%)$ had poor sleep quality. While there were 10 female participants who had good sleep quality $(11.6 \%)$ and 39 participants $(45.3 \%)$ had poor sleep quality. The number of X University students who have poor sleep quality is more than good sleep quality. This shows that the overall sleep quality of $\mathrm{X}$ University students is poor.

This finding is in line with Widjaja's research at Tarumanagara University entitled The Correlation between Sleep Quality and Premenstrual Syndrome (PMS) in Tarumanagara University Faculty of Medicine Students Class of 2016. The study had 96 participants as students of the Tarumanagara University Medical Faculty. As many as 24 students $(25 \%)$ had good sleep quality and 72 students (75\%) had poor sleep. This shows that there are more female students with poor sleep quality than good sleep quality [30].

Poor sleep quality may have been affected by the COVID19 pandemic at the time this research data collection was carried out. The findings of this study that more $\mathrm{X}$ University students have poor sleep quality is in line with a study conducted by Huang and Zhao in China regarding sleep during the COVID-19 pandemic [15]. The study conducted a web-based survey that found a high prevalence of the Chinese population suffering from anxiety disorders and poor sleep. Symptoms that arise are more common in the age group under 35 years. These findings provide evidence support to identify a source of public panic during the COVID-19 pandemic.

In this study, the results of the correlation test between sleep quality and emotional regulation, the cognitive reappraisal dimension, had a statistically insignificant relationship, namely $\mathrm{p}=0.684$ ( $\mathrm{p}>0.05$ ). In addition, the correlation test of sleep quality with emotional regulation of the expressive suppression reappraisal dimension had a statistically insignificant correlation, namely $p=0.291$ ( $p>$ 0.05 ). This study found a correlation between sleep quality and emotional regulation, which was not statistically significant, namely $\mathrm{p}=0.779$ ( $\mathrm{p}>0.05$ ). Thus, it is known that there is no significant correlation between sleep quality and the two dimensions of emotional regulation, both cognitive reappraisal and expressive suppression reappraisal in $\mathrm{X}$ University students. This indicates that 
there is a mismatch between the research hypothesis and the research findings.

This finding is not in line with a number of literature which states that an individual who wants to have good emotional regulation must be based on good sleep quality [13]. Setyowaty conducted a study entitled The Correlation between Sleep Quality and Emotional Stability and the Academic Achievement of Voca Erudita Choir Student Academic Achievement at UNS (Negeri Surakarta University). This research was conducted in 2013 with 60 participants consisting of active students who are members of the Voca Erudita Choir, Negeri Surakarta University [13].

The findings of this study are in line with research by Bower, J. L., Laughlin, M., Simpson, R. J., Connaboy, C., \& Alfano, C. A. in the United States with 16 participants aged 29 to 52 years. Total sleep time is a component that is also measured in the sleep quality questionnaire used in this study, namely the PSQI. The study found that total sleep time was not associated with individual difficulty regulating emotions and poor self-regulation [5].

Based on the data obtained, research on the Correlation between Sleep Quality and Emotional Regulation in X University Students found no relationship between sleep quality and emotional regulation in X University students. This could occur because of other factors that influence emotional regulation. According to Gross, there are three factors that can influence emotional regulation, namely the goal of regulating emotions, frequency of emotion regulation, and personality [32]. The objective factor for emotional regulation is the various things that an individual believes that can influence experiences, emotional expressions and physiological responses that are appropriate to the situation being experienced. The individual frequency factor regulates emotions, related to how often the individual concerned regulates emotions in various different ways [2]. The third factor is the individual's personality itself. The ability of each individual to regulate emotions can also be influenced by the uniqueness of the traits that individual has. McCrae and Costa's research found that there is a relationship between agreeableness personality and how an individual expresses the negative emotions he is feeling [2].

Another factor that can influence the emotional regulation of an individual is gender. In this study, most of the participants were female. There are different ways of expressing emotions between men and women which are associated with different goals in regulating emotions [2]. The study found that women express more emotion to maintain interpersonal relationships, and make them appear weak and helpless. In contrast to men, they express more emotional anger and pride to maintain and show dominance. According to Salovey and Sluyter, girls seek support and protection from those around them to regulate their negative emotions, while boys use physical exercise to regulate their negative emotions [22].

It is possible that there were other factors that could have influenced the results of this study, which the researchers did not study. Various factors can cause a person's poor sleep quality, such as stress, an uncomfortable sleeping environment, consumption of psychoactive substances such as coffee, poor sleep habits, and age. These factors can affect your circadian rhythm, which can affect sleep quality. In addition, a family history of poor sleep quality can also increase a person's risk of poor sleep quality. Several factors can also cause poor emotional regulation of a person, such as excess BMI (body mass index), smoking, frequent fast-food consumption, excessive caffeine consumption, or the presence of family members who have poor emotional regulation. These factors can affect hormones, such as serotonin and cortisol, thereby increasing the risk of having bad emotional regulation [30].

\section{CONCLUSIONS}

Based on the results of the research data analysis, it is concluded that there is no significant relationship between sleep quality variables and emotional regulation in $\mathrm{X}$ University students. There is also no significant relationship between sleep quality variables and the two dimensions of emotional regulation, namely cognitive reappraisal and expressive suppression reappraisal. at $\mathrm{X}$ University students.

\section{ACKNOWLEDGMENT}

Thank you profusely to all parties who have helped carry out this research, namely the Tarumanagara University Research and Community Service Institute who supported the funding for this research.

\section{REFERENCES}

[1] S. Ali, N. Alea, Validating the emotion regulation questionnaire (erq) in trinidad, Journal of Psychiatry and Behavioral Sciences, vol. 1003, p. 1, 2018.

[2] J.W. Permono, C. Kusristanti, Olahraga dan regulasi emosi: sebuah studi korelasi pada taruna perguruan tinggi kedinasan (ptk), Jurnal Psikologi Ulayat, vol. 3, 2016, pp. 169-180.

[3] J. Backhaus, K. Junghanns, A. Broocks, D. Riemann, F. Hohagen, Test-retest reliability and validity of the pittsburgh sleep quality index in primary insomnia, Journal of Psychosomatic Research, 53, 2002, pp. 737-740. DOI: https://doi.org/10.1016/S00223999(02)00330-6

[4] D.S. Black, G.A. O'Reilly, R. Olmstead, E.C. Breen, M.R. Irwin, Mindfulness meditation and improvement in sleep quality and daytime impairment among older adults with sleep disturbances: a 
randomized clinical trial, JAMA Internal Medicine, vol. 175, 2015, pp. 494-501.

[5] J.L. Bower, M. Laughlin, R.J. Simpson, C. Connaboy, C.A. Alfano, 0197 Associations between sleep and emotion regulation in isolated, confined, and extreme environments, Sleep, vol. 41, 2018, p. A77.

[6] M.E. Cates, A. Clark, T.W. Woolley, A. Saunders, Sleep quality among pharmacy students, American Journal of Pharmaceutical Education, vol. 79, 2015.

[7] R.R. Diana, F. Nashori, Perbedaan kualitas tidur dan kualitas mimpi antara mahasiswa laki-laki dan mahasiswa perempuan, Humanitas: Jurnal Psikologi Indonesia, vol. 2, 2005, pp. 77-88.

[8] E.L. Doolan, R.A. Bryant, B.J. Liddell, A. Nickerson, The conceptualization of emotion regulation difficulties, and its association with posttraumatic stress symptoms in traumatized refugees, Journal of Anxiety Disorder, vol. 50, 2017, pp. 7-14.

[9] M.T Dryman, R.G. Heimberg, Emotion regulation in social anxiety and depression: a systematic review of expressive suppression and cognitive reappraisal, Clinical Psychology Review, vol. 65, 2018, pp. 17-42. DOI: https://doi.org/10.1016/j.cpr.2018.07.004

[10] H. Fadilah, Hubungan regulasi emosi dengan adversity quotient pada mahasiswa yang sedang menyusun skripsi di fakultas $\mathrm{x}$ universitas $\mathrm{y}$, Thesis, Jakarta, 2019.

[11] J.R. Fraenkel, N.E. Wallen, H.H. Hyun, How to design and evaluate research in education (8th ed.), New York, Mc Graw Hill, 2012.

[12] A. Friedrich, A.A. Schlarb, Let's talk about sleep: a systematic review of psychological interventions to improve sleep in college students, Journal of Sleep Research, vol. 27, 2017, pp. 4-22.

[13] T. Gusmao, J. Wiyono, V.M. Ardiyani, Hubungan kualitas tidur dengan kecerdasan emosional pada lansia permaditlogosuryo malang, Nursing News: Jurnal Ilmiah Keperawatan, vol. 3, Malang, 2018.

[14] K. Herawati, D. Gayatri, The correlation between sleep quality and level of stress among students in Universitas Indonesia, Enfemeria Clinica, 2019.

[15] Y. Huang, N. Zhao, Chinese mental health burden during covid-19 pandemic, Asian Journal of Psychiatry, vol. 51, 2020.
[16] Jumiarni, Perbandingan kualitas tidur menggunakan skala pittsburgh sleep quality index (psqi) pada pasien gangguan cemas yang mendapat terapi benzodiazepine jangka panjang dan jangka pendek, Thesis, UNHAS, 2018.

[17] Y. Komada, Relationship of women's reproductive health and menstrual problems with sleep and circadian rhythm, Sleep and Biological Rhythms, vol. 18, 2019.

[18] A.R.N. Manalu, E. Bebasari, W.R. Butar butar, Hubungan kualitas tidur dengan tekanan darah pada mahasiswa fakultas kedokteran universitas riau angkatan 2012, Thesis, 2012.

[19] I.N. Nasution, Hubungan kontrol diri dengan perilaku sulit tidur (insomnia), Psychopolytan: Jurnal Psikologi, vol. 1, 2017, pp. 39-48.

[20] H. Nifilda, N. Nadjmir, H. Hardisman, Hubungan kualitas tidur dengan prestasi akademik mahasiswa program studi pendidikan dokter angkatan $2010 \mathrm{fk}$ universitas andalas, Jurnal Kesehatan Andalas, vol. 5, 2016.

[21] M.G. Nio, Hubungan antara kualitas tidur dengan kecerdasan emosional pada komunitas band cafe, Thesis, Sanata Dharma University, Yogyakarta, 2010.

[22] G. Estefan, Gambaran proses regulasi emosi pada pelaku self injury, Thesis, Esa Unggul University, Jakarta, 2014.

[23] L.K. Pilz, L.K. Keller, D. Lenssen, T. Roenneberg, Time to rethink sleep quality: psqi scores reflect sleep quality on workdays, Sleep, vol. 41, 2018. DOI: https://doi.org/10.1093/sleep/zsy029

[24] A.A. Putri, R. Ruhyana, Hubungan antara kualitas tidur dengan konsentrasi belajar dan indeks prestasi mahasiswa program diii kebidanan stikes aisyiyah Yogyakarta, Thesis, 2012.

[25] J. Safriyanda, D. Karim, A.P. Dewi, Hubungan antara kualitas tidur dan kuantitas tidur dengan prestasi belajar mahasiswa, Jurnal Online Mahasiswa Program Studi Ilmu Keperawatan Universitas Riau, vol. 2, Riau, 2015, pp. 1178-1185.

[26] E.A.P Setyowati, Hubungan antara kualitas tidur dan kestabilan emosi dengan prestasi akademik mahasiswa aktif paduan suara voca erudite uns, Thesis, UNS, Surakarta, 2013.

[27] S. Sastroasmoro, Dasar-dasar metodologi penelitian klinis, Jakarta, Saung Seto, 2011. 
[28] N.M.H. Sukmawati, I.G.S.W. Putra, Reliabilitas kuesioner pittsburgh sleep quality index (psqi) versi bahasa indonesia dalam mengukur kualitas tidur lansia, Wicaksana: Jurnal Lingkungan dan Pembangunan, vol. 3, 2019, 30-38.

[29] P.P. Tyas, Regulasi emosi pasca putus cinta pada remaja tahap akhir, Thesis, Muhammadiyah Surakarta University, Surakarta, 2012.

[30] T. Widjaja, Hubungan antara kualitas tidur dengan premenstrual syndrome (pms) pada mahasiswa fakultas kedokteran universitas tarumanagara angkatan 2016, Thesis, UNTAR, Jakarta, 2018.

[31] D. Yilmaz, F. Tanrikulu, Y. Dikmen, Research on sleep quality and the factors affecting the sleep quality of the nursing students, Current Health Sciences Journal, vol. 43, 2017, pp. 20-24. 